\title{
Renata Karkowska* \\ THE APPLICATION OF GARCH (1.1) MODEL FOR MEASURING SHOCKS TRANSMISSION IN BOND MARKET
}

\begin{abstract}
The object of the study is identification of the bond yields volatility in selected European countries, during the crisis of public finances of Greece from 2010 to 2013. For this purpose the GARCH (1.1) model was used. The specific aim of the study is determination of the so-called contagion effect in treasury bonds market. The analysis was conducted in two trials : 1/ for the countries of Central and Eastern Europe, represented by the Czech Republic and Poland, 2/ for developed countries - Austria and France.
\end{abstract}

Keywords: Volatility, Treasury Bonds Market, Credit Spread, GARCH Model.

\section{INTRODUCTION}

The term of transmission channel is defined as an international connection between two or a greater number of economies through which conditiondependent changes can be transmitted. Undoubtedly, knowledge of reasons for credit and liquidity risk fluctuations is a significant facilitation for effective investment portfolio management. It seems that risk reduction should be based on the analysis of correlation coefficients between financial series. The instability of correlation coefficients makes it significantly difficult to manage portfolio and estimate probability of obtaining certain return.

The recent financial and fiscal crisis caused a rapid increase in sovereign bond yields in countries with a weak macroeconomic and fiscal position (Greece, Ireland and Portugal), that was particularly vulnerable to international financial crises. In contrast, in countries with stronger economic fundamentals like Germany or France, long-term interest rates declined as a result of flight-toquality. In the years 2010-2012 the Greek sovereign debt markets fell into severe stress and the crisis began to spread to other European countries.

In the analysis we put forward a hypothesis that, during the fiscal crisis of 2010-2012 there was a transfer of credit spreads volatility in treasury bonds market, but the effect was diverse geographically. Mostly within the similar risk-

\footnotetext{
* Ph.D. Faculty of Management, University of Warsaw, e-mail: rkarkowska@wz.uw.edu.pl
} 
group of countries. Therefore, the aim of the study is to determine whether we deal with the so-called contagion effect in treasury bonds market. For this purpose we use GARCH (1.1) model.

The paper is organized as follows: Section 2 gives a brief overview of volatility determinants in treasury bonds market; Section 3 presents the used data and methodology; Section 4 provides results of GARCH model of volatility on selected treasury bond markets and Section 5 presents conclusions.

\section{LITERATURE REVIEW}

The problem of the risk management in economic crisis has been the subject of numerous studies (Allen, Franklin, Gale 2000 et al.), (Brylius 2010). Bertero and Mayer (1987) found that periods of turbulence in the financial markets are characterized by increasing correlation, which explains the dominance of global over local factors. This phenomenon causes that minimization of risk, based on the diversification of the portfolio may not produce the desired effect, because due to the higher correlation during the crisis, a decline in the value of $\mathrm{X}$ asset will decline in value of an $\mathrm{Y}$ asset.

The size of shaping the credit spread is a frequently examined phenomenon. One of research studies presents a credit spread sources in default and nondefault factors. The results of research analysis proved that factors associated with default accounted for a greater percentage of the total credit spread, classified to lower rating class: $51 \%$ spread of bonds are default factors in AAA/AA class, $56 \%$ in A class, $71 \%$ in BBB class, $83 \%$ in BB class. Factors associated with the issuer's non-default and affecting the size of a credit spread are liquidity and taxes (Longstaff et. al. 2004). The researches on the size of a credit spread in the bonds market were carried out mainly for corporate bonds in advanced economies, for issues at investment and speculative levels (Chen, 2007). The results indicate that non-liquid bonds lead to higher changes in credit spreads and the size of credit spreads decreases along with increasing liquidity. The research also emphasizes that the change of credit spread is not completely explained by the issuer's default risk. It may suggest the presence of the other factors, e.g. contagion on international scale. On the other hand, Ericsson and Renault (2002) revealed that the levels of credit spread on the bonds market were correlated positively with the issuer's default risk and its size decreases along with assets' maturity. Han and Zhou (2007) suggest that non-default components of credit spreads of bonds can be subject to fluctuations under the effect of macroeconomic and financial changes, such as structure of the Treasury bonds market and implied volatility on the stock exchange market. Also, the lack of liquidity on the CDS market is reflected in significant changes in credit 
spreads. Theoretically, in the liquid market the levels of credit spreads of bonds should be reflected in the CDS prices, but the researches do not confirm it in emerging markets. Zhu (2006) proves that the interrelations between the CDS prices and credit spreads were positive only for mature markets in the long run, while for short term the correlation does not exist. The contagion effect as the transmission of the crisis to the economy, resulting in real and financial relations with other countries, is particularly important in the case of portfolio management on an international scale (Karkowska, 2012).

The most common feature of daily returns in stock market indices is the phenomenon of grouping variances and lack of randomness of these changes. Therefore, in modeling of financial processes the ARCH econometric models are commonly used. They are the tools which make it easy to answer the question about the relationship between the various financial processes (e. g. the values of indices, exchange rates, the price of stocks, bonds, interest rates). The world study on the relationship between the volatility of rates of return on the stock markets with the use of single-equation or multi-equation models was conducted by Engle and Susmel (1993), and Ramchand and Susmel (1998). In particular the study focused on the analysis of the impact of volatility from one segment of the financial market (especially major global stock market), such as the foreign exchange, money, or capital markets into other geographical areas. The results of empirical studies are not conclusive. For example, French et. al. (1987) and Engle et. al. (1987) show a positive relationship between the expected rate of return and the conditional variance. Backus and Gregory (1993) noted that the relationship between the risk premium and the conditional variance is usually the nature of anything. On the other hand, Glosten et. al. (1993) argue that there is a negative relationship between the expected rate of return and variance. The works of Domowitz and Hakkio (1985) show, that the relationship between the expected rate of return and the risk was not statistically significant. However, the research confirms that daily volatility in trading stock indices in emerging markets in Europe exhibits similar properties as in developed markets.

\section{DATA AND METHODOLOGY}

As our research is focused on the impact of the crisis in public finances in Greece on the variability of credit risk on the bonds market in Europe, we used daily observations from the period of 2010/06/16-2013/09/01. The source of data was the database Thomsom Reuters Eikon. The research includes also geographical distinction; four markets with diverse investment risk levels were selected. The first group includes Central and Eastern Europe countries: Poland (PL) and the Czech Republic (CZ), defined by investors as developing markets. 
The second group includes: Austria (AT) and France (FR), which are considered mature markets. Each group included also Greece (GR), as an important source/cause of market changes.

Variability of credit spread on bonds was modeled, using the GARCH (1.1) model.

Credit spreads $-B O N D C S_{t}$ were calculated according to the following formulas:

$$
B O N D C S_{t}=B O N D_{t}-B O N D G E_{t}
$$

where:

$B O N D t$ - average yield of Tbonds (10Y maturity ), measured in basic points, $B O N D G E t$ - average yield of German Tbonds (10Y maturity), measured in basic points,

For the purpose of the study we selected the most liquid benchmark $10 \mathrm{Y}$ Treasury bonds yields: 2 from emerging markets: the Czech Republic and Poland, and 2 from developed countries: France and Austria. As the main source of volatility $10 \mathrm{Y}$ Greek bond was selected. The sample covered the period 2010/06/16-2013/09/01. Model estimation of rate of return and volatility credit spread was based on the GARCH (1.1) model. This choice was preceded by an analysis of the information criteria - Akaike, Hannan-Quinn, Schwarz and Shibata (Maddala 2006: 209-210).

The model introduces a first-order autoregression for the dependent and the independent variables. This has been carried out on the basis of earlier Quenouille'a autocorrelation coefficient test. Autocorrelation function (ACF) and partial autocorrelation (PACF), autocorrelation test Ljung-Box (Q) returns processes of individual credit spread: GRCS (Greece), CZCS (Czech R.), PLCS (Poland), FRCS (France), ATCS (Austria), with a significance level of $\alpha=0.05$, indicated the autocorrelation first order AR(1). Test results the presence of $\mathrm{ARCH}$ effect in the sample for each of 5 countries. Testing helped determine, that the observed correlation at random components is non-apparent. The verification is based on Lagrange multiplier test statistics (Maddala 2006: 213) and is presented in Table 1.

Table 1. The values of the Lagrange multiplier test statistics

\begin{tabular}{|l|c|c|c|c|c|}
\hline & GRCS & CZCS & PLCS & FRCS & ATCS \\
\hline $\mathrm{LM}=\mathrm{TR}^{2}$ & 742,706 & 423 & 590,06 & 490,438 & 638,192 \\
\hline
\end{tabular}

Source: own calculations. 
The output of hypotheses test about the impact of external shocks from one country on the $n$-th country is the following regression's equation:

$$
y_{n}=\sum_{i=1}^{n} \alpha_{n i} y_{i t}+\varepsilon_{t}
$$

Testing how much the bond market is vulnerable to external influence is based on the verification of the hypothesis:

$$
\begin{gathered}
H_{0}: y_{n 1}=\ldots=: y_{n m-1}=y_{n m+1}+\ldots=y_{m}=0 \\
H_{1}: \sim H_{0}
\end{gathered}
$$

Hypothesis (3) has been tested using the likelihood ratio statistics for GARCH and Schwarz Bayesian criterion. In Table 2 we present the estimated parameters of basic model (2) for selected treasury bonds and hypothesis (3) is verified. In any case, null hypothesis $\mathrm{H}_{0}$ was rejected (the lack of ARCH effect) in favor of alternative hypothesis of variance of the random component. General GARCH (1.1) model estimates the bonds credit spread volatility between selected countries is presented as follow:

$$
\begin{gathered}
Y_{t}=\alpha_{0}+\alpha_{11} Y_{t-1}+\alpha_{21} X_{1, t}+\alpha_{31} X_{2, t}+\alpha_{41} X_{3, t}+\alpha_{51} X_{4, t}+\varepsilon, \varepsilon_{t} \in D\left(0, h_{t}\right) . \\
X_{k, t}[G R C S, F R C S, A T C S, C Z C S, P L C S] \\
h_{t}=\beta_{0}+\sum_{i=1}^{q} \beta_{1 i}\left(\varepsilon_{t-i}\right)^{2}+\sum_{i=1}^{p} \delta_{l i} h_{t-i},
\end{gathered}
$$

where:

$Y_{t}$ - dependent variable of daily $\log$ bond credit spread changes in country $Y$, $Y_{-1}$ - lagged $Y$ variable,

$X_{k, t}-$ independent variable of daily log bond credit spread changes in subsequent countries.

Similarly, to examine the vulnerability of other countries to shocks from the outside, the following parameters were estimated with the use of GARCH models. The results of model parameters estimated by GARCH (1.1) are presented in Table 2 . 


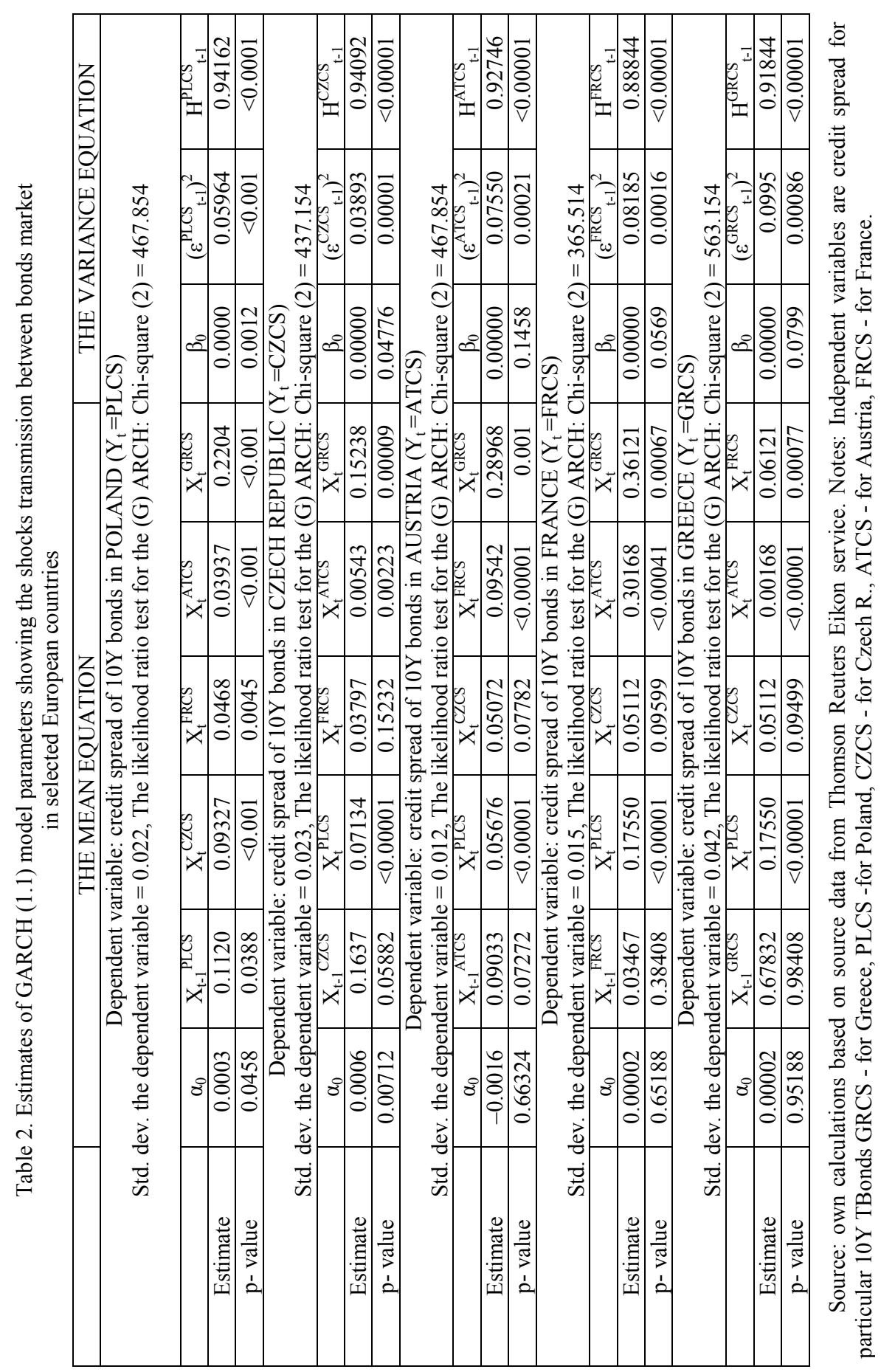




\section{EMPIRICAL RESULTS}

Verification of the hypothesis (3) for each of the bond markets shows, that the likelihood ratio statistic test is high, which suggests that it is necessary to reject the $\mathrm{H}_{0}$, that selected bond markets are not vulnerable to shocks coming from outside. On the basis of the estimated parameters we find that all the credit spread is subject to the greatest influence of the Greek market. All estimates are significant. The growing importance of the Greek capital market effects confirms the initial assumptions. The contagion effect of the credit spreads volatility remained mostly within the same risk-group of countries. We can observe a greater impact on Poland and the Czech Republic, belonging to the group of emerging markets in Europe. Similar results are obtained in the group of developed countries - Austria and France. Reactions between these groups are smaller. The results show that developed bond markets are more susceptible to shocks coming from Poland and the Czech Republic. In total, negative shocks of Greek treasury bonds market have a significant influence on other markets in Europe.

\section{CONCLUSIONS}

In this paper we have studied the impact of the fiscal crisis in Greece on treasury bond credit spread in five European markets. We have examined the crisis effects with an empirical model where we control the contagion effect of credit risks. The results confirm the initial hypothesis, that changes in spread of Greek bonds yield cause changes in other treasury bonds markets. Reverse interrelations were definitely less significant. The phenomenon of volatility transfer of credit spreads remained mostly within the similar risk-group of markets.

We find that the Greek public finances crisis has significant effects on the sovereign yields, at least in the short run. As expected, it has caused different kinds of reaction across European countries.

Finally, we understand that credit spread changes are caused by the changes in the investors risk appetite, but also the expectations related to the changes in macroeconomic fundamentals. The present study will lead us to the next step in the bond spread variation analysis in the context of pro-cyclicality.

\section{REFERENCES}

Allen F., D. Gale (2000), Financial Contagion, "The Journal of Political Economy", Vol. 108, No. 1 , s. $1-33$.

Backus D.K., A.W. Gregory (1993), Theoretical Relations between Risk Premiums and Conditional Variances, "Journal of Business \& Economic Statistics”, Vol. 11. No. 2.

Bertero E., C. Mayer (1987), Structure and Performance. Global Interdependence of Stock Markets around the Crash of October, "European Economic Review", Vol. 34. 
Brylius P. (2010), Economic crisis and SMEs sustainability policies: application of emotional well-being function for analysis, "Journal of Advanced Research in Management", vol. I.

Chen, L., D. Lesmond, J. Wei (2007), Corporate yield spreads and bond liquidity, "The Journal of Finance", 62(1), 119-149.

Domowitz I., Hakkio C. S. (1985), Conditional variance and the risk premium in the foreign exchange market, "Journal of International Economics", vol. 19(1-2), pp. 47-66.

Engle R., Susmel R. (1993), Common Volatility in International Equity Markets, "Journal of Business \& Economic Statistic", Vol. 11. 167-176.

Engle R.F., D.M. Lilien, R.P. Robins. (1987), Estimating time varying risk premia in the term structure. The ARCH-M Model, "Econometrica", vol. 55. 391-407.

Ericsson, J. and O. Renault (2002), Liquidity and credit risk, "The Journal of Finance", 61(5), 2219-2250.

French K. R., Schwert G. W., Stambaugh R. (1987), Expected Stock Return and Volatility, "Journal of Financial Economics", 19. pp. 3-29.

Glosten L. R., Jagannathan R., Runkle D. E. (1993), On the Relation Between the Expected Value and the Volatility of the Nominal Excess Return on Stocks, "Journal of Finance", 48. 17791801.

Han, S. H. Zhou (2007), Nondefault bond spread and market trading liquidity.

Karkowska R. (2012), Towards a Measurement Scale for Contagion Effect on Capital Market, "Journal of Advanced Research in Management", Vol. III, Issue 2(6).

Longstaff F., Mithal S., Neis E., (2004), Corporate Yield spreads: default risk or liquidity? New evidence from the credit-default swap market, "NBER Working Paper", April.

Maddala G. S. (2008), Econometrics, Publisher PWN. Warsaw.

Ramchand L., Susmel R. (1998), Volatility and Cross Correlation cross Major Stock Markets, "Journal of Empirical Finance", 5. 397-416.

Zhu, H. (2006), An empirical comparison of credit spreads between the bond market and the credit default swap market, "Journal of Financial Services Research", 29(2), 211-235.

Renata Karkowska

\section{ZASTOSOWANIE MODELU GARCH (1.1) DO SZACOWANIA TRANSMISJI SZOKÓW NA RYNKU OBLIGACJI}

Streszczenie. Celem badania jest identyfikacja zmienności spreadu kredytowego obligacji w wybranych krajach europejskich, w czasie kryzysu finansów publicznych Grecji w latach 2010 2013 roku. W badaniu wykorzystano model GARCH (1.1). Szczególnym celem badania jest ustalenie: czy na rynku obligacji skarbowych mamy do czynienia z efektem zarażania? Analizę przeprowadzono w dwóch próbach: 1/ dla krajów Europy Srodkowej i Wschodniej, reprezentowanej przez Czechy i Polskę, 2/ w krajach rozwiniętych - w Austrii i Francji.

Słowa kluczowe: zmienność, rynek obligacji skarbowych, spread kredytowy, model GARCH 